\title{
Valuation of air pollution externalities: comparative assessment of economic damage and emission reduction under COVID-19 lockdown
}

\author{
Hemant Bherwani ${ }^{1,2}$ (D) Moorthy Nair ${ }^{3} \cdot$ Kavya Musugu $^{1} \cdot$ Sneha Gautam $^{4}$ - Ankit Gupta ${ }^{1,2}$ - Atya Kapley ${ }^{1,2}$. \\ Rakesh Kumar ${ }^{1,2}$
}

Received: 19 May 2020 / Accepted: 27 May 2020 / Published online: 10 June 2020

(C) Springer Nature B.V. 2020

\begin{abstract}
Air pollution (AP) is one of the major causes of health risks as it leads to widespread morbidity and mortality each year. Its environmental impacts include acid rains, reduced visibility, but more importantly and significantly, it affects human health. The price tag of not managing AP is seen in the rise of chronic obstructive pulmonary disease (COPD), cardiovascular disease, and respiratory ailments like asthma and chronic bronchitis. But as the world battles the corona pandemic, COVID-19 lockdown has abruptly halted human activity, leading to a significant reduction in AP levels. The effect of this reduction is captured by reduced cases of morbidity and mortality associated with air pollution. The current study aims to monetarily quantify the decline in health impacts due to reduced AP levels under lockdown scenario, as against business as usual, for four cities - Delhi, London, Paris, and Wuhan. The exposure assessment with respect to pollutants like particulate matter $\left(\mathrm{PM}_{2.5}\right.$ and $\left.\mathrm{PM}_{10}\right), \mathrm{NO}_{2}$, and $\mathrm{SO}_{2}$ are evaluated. Value of statistical life (VSL), cost of illness (CoI), and per capita income (PCI) for disability-adjusted life years (DALY) are used to monetize the health impacts for the year 2019 and 2020, considering the respective period of COVID-19 lockdown of four cities. The preventive benefits related to reduced AP due to lockdown is evaluated in comparison to economic damage sustained by these four cities. This helps in understanding the magnitude of actual damage and brings out a more holistic picture of the damages related to lockdown.
\end{abstract}

Keywords Air pollution · Coronavirus · COVID - $19 \cdot$ Externalities · Economy $\cdot$ Mortality

\section{List of abbreviations}

AP Air pollution

COPD Chronic obstructive pulmonary disease

VSL

CoI

PCI

DALY

SARS-CoV-2

Hemant Bherwani

h.bherwani@neeri.res.in

1 CSIR-National Environmental Engineering Research Institute (CSIR-NEERI), Nehru Marg, Nagpur, Maharashtra, India

2 Academy of Scientific and Innovative Research (AcSIR), Ghaziabad, Uttar Pradesh, India

3 Asian Development Research Institute (ADRI), Patna, Bihar, India

4 Karunya Institute of Technology and Sciences, Coimbatore, Tamil Nadu, India

\author{
Severe acute respiratory \\ syndrome coronavirus 2
}

WHO World Health Organization

LERC Linear exposure-response curve

GDP Gross domestic product

INR Indian rupee

USD US dollar

M\$ Million USD

B\$ Billion USD

\section{Introduction}

The cost of development has had a major impact on the ecosystem balance. One major fallout is the jeopardized air environment (Mage et al. 1996). This is mainly due to a plethora of emission of pollutants such as $\mathrm{PM}_{10}, \mathrm{PM}_{2.5}, \mathrm{NO}_{2}, \mathrm{SO}_{2}$, etc. from various anthropogenic activities such as transportation, industrial processes, mining activities, waste burning, biomass burning, residential cooking, etc. (Nair et al. 2020; Gupta et al. 
2020; Humbal et al. 2019; Bherwani et al. 2019; Gautam et al. 2016). Deteriorated air causes long- and short-term health effects such as chronic obstructive pulmonary disease (COPD), asthma, respiratory mortality, cancer, cardiovascular mortality, etc. (Kim et al. 2015; Ghorani-Azam et al. 2016; Maji et al. 2017; Cohen et al. 2017; Landrigan et al. 2018) among humans. This global threat is considered as one the leading cause for mortality and accounts for 7 million lives every year, estimating a total cost of more than $4 \%$ of the GDP (WHO 2020). Extensive studies have been carried out by various researchers (Gulia et al. 2015; Maji et al. 2017 \& Maji et al. 2018) in heavily polluted cities to quantify the healthrelated monetary burden upon the exposure of human in the deteriorated air environment.

Severe acute respiratory syndrome coronavirus 2 (SARSCoV-2) outbreak firstly identified in Wuhan City, China (WHO 2020; Gautam and Hens 2020; Gautam and Trivedi 2020; Gautam 2020a) has now become a pandemic across the globe, resulting in about 3.5 million cases in just about 4 months (Bherwani et al. 2020; WHO 2020). The pandemic has declared global health emergency enforcing lockdown measures in activities (i.e., social contact, non-essential business, mobility, etc.) to flatten the epidemic curve. Lockdown measures have shut down industries, halted vehicular traffic, and have had a huge impact on the daily routine of the people. Due to this, considerable improvement in air quality levels of countries such as Spain (Tobias et al. 2020), India (Gautam 2020b), Brazil (Nakada and Urban 2020), and China (Sharma et al. 2020), and in cities such as Bangkok, Tokyo, Paris, and New York (He et al. 2020) has been reported. The plummet in pollutant concentration is obvious due to the restriction in anthropogenic activities.

The air quality during the lockdown period for majorly polluted cities (i.e., Delhi, Wuhan, Paris, and London) is of high significance in determining the baseline pollution level and attributable health risk, to evaluate the potential fluctuation in monetary damages. Assessment in terms of the number of lives affected is important, but a common baseline matrix such as "money" carries a much better message for the sake of understanding and decision making (Gautam 2020a). An unprecedented attempt has been made to quantify the economic benefit due to reduction in an excess number of health risk subject to mortality/morbidity attributable to lower air pollutant $\left(\mathrm{PM}_{2.5}, \mathrm{PM}_{10}, \mathrm{NO}_{2}\right.$, and $\left.\mathrm{SO}_{2}\right)$ concentration in Wuhan, Paris, London, and Delhi. Figure 1 indicates the geographical location of the cities.

The monitored ground-based pollutant concentration are compared with WHO ambient air quality guidelines (WHO 2006) to evaluate the relative risk associated with each disease and thereby, the subsequent damage cost. The economic benefit/loss is calculated for each city based on the difference in excess number of health cases attributable to pollutant concentration during the lockdown period for 2020 and 2019. The study has also considered the overall benefit due to mass reduction in air pollutant level over the potential economic loss to the local and national government as an outcome of lockdown.

\section{Methodology}

\section{Population (N) and air quality}

Population for the years of valuation is estimated to evaluate the extent of health damages due to AP in a particular city. Population data is collected for 2019 and 2020 for calculating the number of people affected due to AP. The population of Delhi, London, Paris, and Wuhan has increased from 185, 91.8, 109.6, and 82. 6 lakhs in 2019 to 195, 83.60, 93.00, and 110.2 lakhs in 2020, respectively (Economic Survey of Delhi 2019).

Lockdown is imposed in many countries due to the outbreak of COVID-19 (Wang et al. 2020a; Dutheil et al. 2020; Gautam 2020b). In Delhi, the lockdown was imposed from March 22 (Economic Times 2020), in Paris from March 18, 2020 (Jon et al. 2020), in London form March 23 (The Hindu 2020), and in Wuhan, it started from January 23 . To analyze the AP levels, 31 days of lockdown is taken for the four cities and the respective data for AP as shown in Table 1 along with dates of lockdown.

Average of 24-h mean data of $\mathrm{PM}_{2.5}, \mathrm{PM}_{10}, \mathrm{SO}_{2}$, and $\mathrm{NO}_{2}$ values are taken in the period of lockdown that is 31 days for the four cities in 2020, and the same duration is taken in 2019 and values are shown in Table 1. Number of people are affected by mortality and morbidity due to the exposure of harmful pollutant concentrations by taking the 24-h mean values for 31 days for these cities is evaluated. The values of people getting affected are calculated on the basis of daily data of pollutants in comparison to daily values of WHO guidelines. The daily values are averaged for month and shown here. $\mathrm{SO}_{2}$ has been found within limits throughout the study period for both the years.

\section{Exposure assessment}

Short-term health effects such as chronic obstructive pulmonary disease (COPD), asthma, respiratory mortality, cardiovascular mortality, and respiratory diseases due to excess pollution level during lockdown period (number of days $(n)=31$ ) for the current and previous years were estimated using linear exposure-response curve (LERC) method.

The assessment was carried considering various factors such as relative risk $R_{r}(m)$ due to mean pollutant concentration, population attributable to risk (PAR) due to exposure of pollutant, baseline incidence cases $\left(I_{e}\right)$ per $10^{5}$ population corresponding to mortality/morbidity health impacts, and the total population of the city $(N)$. Equations (1)-(3) are used for estimating earlier mentioned variables. 
Fig. 1 Study area and geographical location of cities

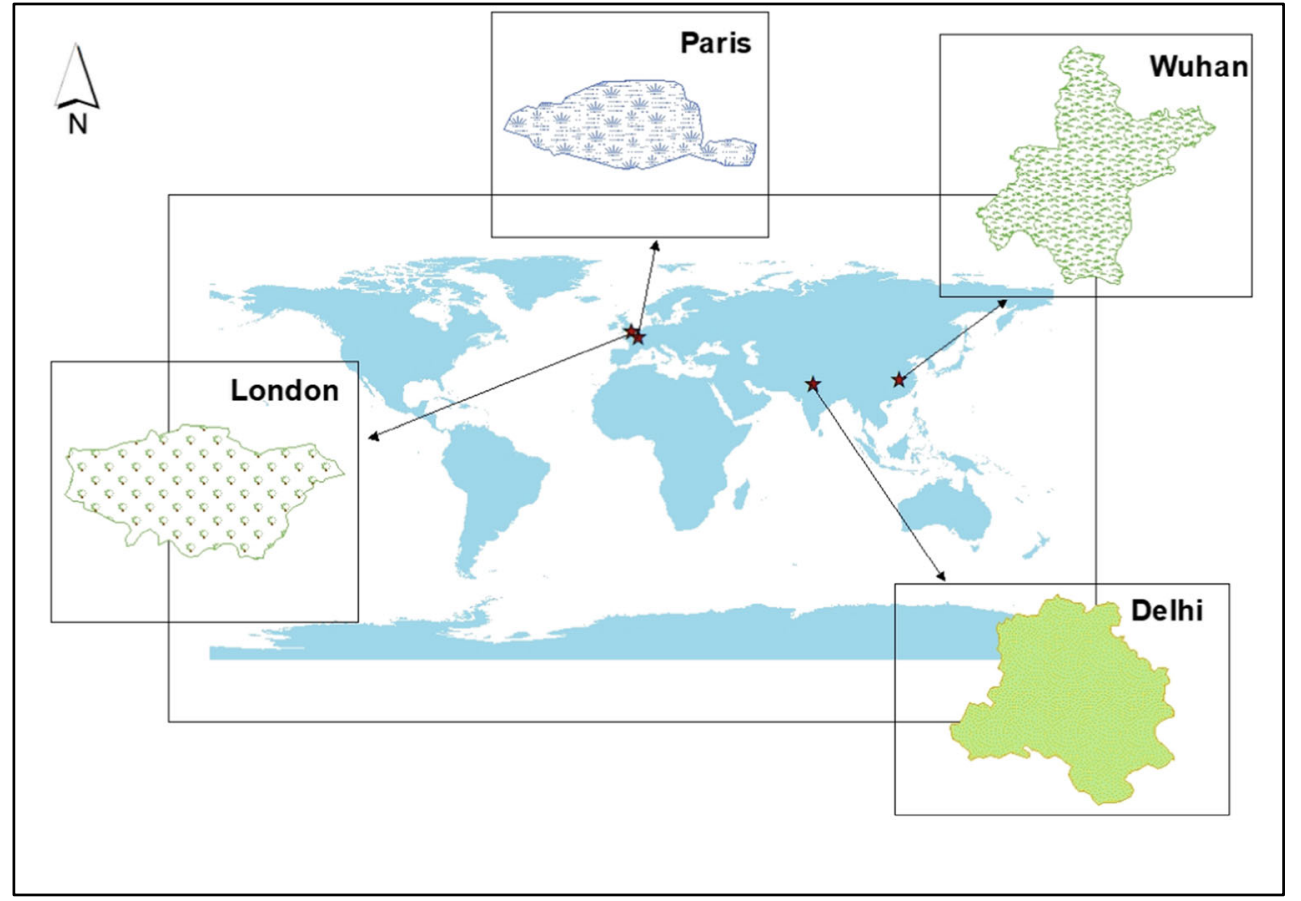

$R r_{m}=1+\left(C_{p}-C_{m}\right) \times(R r-1) / 10$

$$
\begin{aligned}
& P A R=\sum\left[\left\{R r_{m}-1\right\}\right] \times \rho(c) / \sum\left[\left\{R r_{m}-1\right\} \times \rho(c)+1\right] \\
& I_{n e}=I_{e} \times P A R \times N
\end{aligned}
$$

where $C_{m}$ is monitored daily ambient air concentration of pollutant " $\mathrm{K}$ " (daily values of average pollutant loads given in Table 1). $C_{p}$ is permissible standard for the pollutant " $\mathrm{K}$ " (WHO Guideline values). The standards preferred are as put forth by WHO in 2006. $R r$ is relative risk for the pollutant " $\mathrm{K}$," and the values for $R_{r}$ and $I_{e}$ are discussed in Table 2. $\rho(c)$ is the proportion of population being exposed to the pollutant " $K$ " ( $100 \%$ exposure is considered in our study). $I_{n e}$ is the estimated number of cases.

\section{Valuation of AP externalities}

The monetary burden due to health risk is calculated using the methods of VSL, COI, and DALY for mortality and morbidity endpoints. For valuation, morbidity and mortality are evaluated via separate methods. The valuation of mortality is done using VSL which is usually available for each country based on assessments done for either labor wages or insurance settlements. The data on VSL is inflated to the year 2019 (which is the base year of valuation for this research) in the native currency of the reference and is compiled in Table 3.

The exchange rate/conversion factor is used for converting the native currency to USD while the inflation is carried out to bring the value to the base year of 2019. The formula for evaluation of monetary damages of mortality is given as follows:

$($ Mortality)Damages $(\$)=V S L \times I n e \times E R \times I R$

Table 1 Average ambient air quality parameters for cities during lockdown days (31 days) in 2020 and similar period in 2019 (Real-time air quality

\begin{tabular}{|c|c|c|c|c|c|c|c|c|c|}
\hline \multirow[t]{2}{*}{ City } & \multirow[t]{2}{*}{$\begin{array}{l}\text { Lockdown period } \\
\text { in } 2020\end{array}$} & \multicolumn{2}{|c|}{$\begin{array}{l}\text { Mean } \mathrm{PM}_{2.5} \\
\left(\mu \mathrm{g} / \mathrm{m}^{3}\right)\end{array}$} & \multicolumn{2}{|c|}{$\begin{array}{l}\text { Mean } \mathrm{PM}_{10} \\
\left(\mu \mathrm{g} / \mathrm{m}^{3}\right)\end{array}$} & \multicolumn{2}{|l|}{$\begin{array}{l}\text { Mean } \mathrm{NO}_{2} \\
\left(\mu \mathrm{g} / \mathrm{m}^{3}\right)\end{array}$} & \multicolumn{2}{|l|}{ Mean $\mathrm{SO}_{2}\left(\mu \mathrm{g} / \mathrm{m}^{3}\right)$} \\
\hline & & 2020 & 2019 & 2020 & 2019 & 2020 & 2019 & 2020 & 2019 \\
\hline Delhi & March 22-April 21 & 82.00 & 130.00 & 51.00 & 123.00 & \multirow[t]{4}{*}{ With WHO Limits } & With WHO Limits & \multirow[t]{4}{*}{ With WHO Limits } & \multirow[t]{4}{*}{ With WHO Limits } \\
\hline London & March 24-April 23 & 58.50 & 68.00 & 29.00 & 34.00 & & 33.00 & & \\
\hline Paris & March 18-April 17 & 51.60 & 70.00 & 29.00 & 43.00 & & 36.00 & & \\
\hline Wuhan & March 1-March 31 & 119.8 & 145.0 & 50.00 & 75.00 & & 31.00 & & \\
\hline
\end{tabular}
index, Delhi, London, Paris, Wuhan 2020) 
Table 2 Parameters considered for mortality/morbidity (Maji et al. 2017; Maji et al. 2018)

\begin{tabular}{llll}
\hline Parameters & Mortality/morbidity & Relative risk $\left(R_{r}\right)$ & Baseline incidence $\left(I_{e}\right)$ \\
\hline $\mathrm{PM}_{2.5}$ & Total mortality & 1.015 & 543.5 \\
& Respiratory disease & 1.022 & 550.9 \\
& Cardiovascular disease & 1.013 & 546 \\
& Asthma attack & 1.021 & 940 \\
& Chronic bronchitis & 1.029 & 694 \\
$\mathrm{PM}_{10}$ & Total mortality & 1.004 & 1013 \\
& Cardiovascular mortality & 1.006 & 497 \\
& Respiratory mortality & 1.008 & 66 \\
& COPD morbidity & 1.005 & 101.4 \\
& Respiratory disease & 1.004 & 1260 \\
& Cardiovascular disease & 1.002 & 436 \\
& Total mortality & 1.024 & 543.5 \\
$\mathrm{NO}_{2}$ & Cardiovascular mortality & 1.021 & 497 \\
& Respiratory mortality & 1.037 & 48.4 \\
& COPD morbidity & 1.009 & 101.4 \\
& Respiratory disease & 1.006 & 1260 \\
& Cardiovascular disease & 1.010 & 436 \\
\hline
\end{tabular}

where ER is the exchange rate (IMF 2020) and IR is the inflation rate (The World Bank 2019).

On similar lines to mortality, morbidity is valued using cost of illness (COI) and DALY and is added to get total morbidity-related damage assessment. The data related to DALY is taken from the WHO database and is given for the select cities in Table 4.

DALY indicates the years of life lost and thus can be valued using the annual income of an individual. The per capita income (PCI) of the selected cities with their referenced and converted values to USD ( 2019) is shown in Table 5. The formula related to DALY-related morbidity damage valuation is given in Eq. (5).

Morbidity loss $(\mathrm{DALY})(\$)=$ Ine $\times D A L Y \times P C I \times I R \times E R$

Another important related to morbidity is evaluated cost of treatment of the disease, which is done using COI. COI includes total cost incurred such as medicinal cost, travel cost, hospital admission, and lost day. Cost of illness of morbidity of each city is shown in Table 6 as compiled from the literature and converted to USD (2019). For the respiratory disease of Paris, the literature was not available, and hence, the corresponding values in London are used. Similarly, literature indicated very high costs for COPD for Wuhan, and hence, Indian costs for COPD are normalized with reference to asthma costs and used for valuation. The formula for evaluation of morbidity based on $\mathrm{COI}$ is given as follows:

(Morbidity)Damages $(\mathrm{COI})(\$)=C O I \times I n e \times \mathrm{E} R \times I R$

Based on the above inputs, the valuations of morbidity- and mortality-related damages of AP are carried out and explained in the "Results and discussion" section.

\section{COVID-19 lockdown economic damage}

In order to understand the true magnitude of the damages, it is compared to economic damages sustained during the lockdown. The prevention of AP provided a benefit at the cost
Table 3 VSL for each polluted city

\begin{tabular}{llll}
\hline City & $\begin{array}{l}\text { Value of statistical life } \\
\text { (VSL) }\end{array}$ & $\begin{array}{l}\text { VSL (2019) in million US } \\
\text { dollar }\end{array}$ & Author (year) \\
\hline Delhi & INR 44.69 million (2019) & 0.652 & $\begin{array}{c}\text { Majumder and Madheswaran } \\
(2018)\end{array}$ \\
London & Euro 1.83 million (2015) & 2.140 & $\begin{array}{l}\text { Thomas (2018) } \\
\text { Paris }\end{array}$ \\
Euhan & RMB 3.01 million (2017) & 0.455 & $\begin{array}{l}\text { Monzón and Guerrero (2004) } \\
\text { Qu et al. (2020) }\end{array}$ \\
\hline
\end{tabular}


Table 4 Disability-adjusted life years (WHO 2018)

\begin{tabular}{lllll}
\hline Health condition & \multicolumn{4}{l}{ DALY value (per capita) } \\
\cline { 2 - 5 } & Delhi & London & Paris & Wuhan \\
\hline Respiratory disease (including COPD, bronchitis, asthma) & 0.019 & 0.008 & 0.010 & 0.004 \\
Cardiovascular disease & 0.055 & 0.043 & 0.038 & 0.069 \\
\hline
\end{tabular}

of economic damage. For this, economic damage sustained by each city during the lockdown is calculated and compiled, as shown in Table 7. The gross domestic product (GDP) of the city is compared with the GDP of the country to understand the citywide damages as literature only reported country-level damages.

\section{Results and discussion}

Ambient air quality for Delhi, London, Paris, and Wuhan cities for the lockdown month with the number of days for the years 2019 and 2020 as shown in Table 1 is considered for calculating the health damage cost due to air pollutants. During the lockdown days due to limited transportation and industrial output, air pollution is significantly reduced (Wang et al. 2020b). Some of the air pollutants came within the World Health Organization (WHO) guidelines (Jordan 2020) just a few days into the lockdown. $\mathrm{NO}_{2}$ concentration for all the cities during the lockdown is less than the WHO limit every day, whereas breach is observed for the year 2019. Pollutant such as $\mathrm{PM}_{2.5}, \mathrm{PM}_{10}, \mathrm{NO}_{\mathrm{x}}$, and $\mathrm{SO}_{2}$ results in various health damages such as respiratory diseases, COPD, cardiovascular diseases, and mortality. These pollutants are considered to calculate corresponding health damage cost. It can be observed that $\mathrm{SO}_{2}$ concentration was below the acceptable permissible limit set by International guidelines (WHO 2006). Hence, no health damage due to pollutant was considered. The daily mean of $\mathrm{PM}_{2.5}, \mathrm{PM}_{10}$ and daily averages for $\mathrm{NO}_{2}$ during the month of lockdown days in 2020 and the same month for the previous year 2019 was found beyond the acceptable limit, thereby health damage assessment is carried out by certain set of formulas (Eqs. (1)-(3)) (Maji et al. 2017).

In order to quantify the impacts in monetary terms, it is essential to understand the mechanism by which the impact happens. The impact pathway approach (Bherwani et al.
2019; Ghorani-Azam et al. 2016) reveals how emitted pollutants lead to different adverse outcomes on human wellbeing and other natural environments. In the current research, we are primarily focusing on human health impacts of AP, and the same is quantified in monetary terms. Basic parameter of the number of people affected under morbidity and mortality are calculated using Eqs. (1)-(3) using the available data. The factors for each of the pollutant parameter are taken from Table 2. The reference concentration for the pollutants is taken from the WHO guidelines. The cases of morbidity and mortality under each heading of disease for each city are summarized in Table 8 .

While standard deviations have been reported in pollutant concentration, relative risks, and baseline incidences, the resolution of calculation for multiplicative parameters using standard deviation may yield complex variations in the results. Hence, the morbidity and mortality assessments have been done on average values. From Table 8 , it can be seen that $\mathrm{PM}_{2.5}$ is the most damaging parameter affecting many people in all cities. The highest cases are reported in Delhi due to PM; however, no cases due to $\mathrm{NO}_{2}$ in 2019. Since it has the highest number of cases to start with, the lockdown indicates the highest reduction as well. While this will hold true for monetary benefit as well or not is discussed later. Wuhan indicates the second-highest number of people affected; however, reduction in 2020 appears to be low. London and Paris show a similar size of cases. Figure 2 indicates the morbidity and mortality between the two years 2019 and 2020 .

The valuation of morbidity is carried out for cardiovascular and respiratory diseases, including general respiratory ailments, asthma and COPD. COI is used to include the expenditure of treatment, including the outpatient and in-patient costs related to the ailment. The COI for each city, based on national averages, have been used for diseases, as indicated in Table 6. The valuation of the cost of treatment of morbidity is evaluated using Eq. (6). Apart from the treatment expenditure,
Table 5 Per capita income of each city

\begin{tabular}{llll}
\hline City & Per capita income (PCI) & PCI (2019) in US dollar & Author (year) \\
\hline Delhi & INR 4,02,000 (2018) & 6064 & PRS (2019) \\
London & Euro 43,629 (2015) & 52,027 & TUC (2016) \\
Paris & Euro 52,100 (2017) & 62,243 & European Commission (2019) \\
Wuhan & RMB 1,35,136(2018) & 20,044 & CEIC (2018) \\
\hline
\end{tabular}


Table 6 Cost of illness for morbidity assessment

\begin{tabular}{|c|c|c|c|c|}
\hline Cities & Morbidity illness & Cost of illness as reported (year) & Cost of illness USD (2019) & Author (year) \\
\hline \multirow[t]{4}{*}{ Delhi } & COPD & INR 44390 (2005) & 1675 & Koul et al. (2019) \\
\hline & Asthma & USD 637 (2019) & 637 & Ghoshal et al. (2016) \\
\hline & Respiratory disease & USD 637 (2019) & 637 & Ghoshal et al. (2016) \\
\hline & Cardiovascular disease & INR 300000 (2018) & 4522 & Apoorva (2018) \\
\hline \multirow[t]{4}{*}{ London } & COPD & GBP 1640 (2006) & 3028 & Starkie et al. (2008) \\
\hline & Asthma & Euro 169 (2010) & 240 & Mukherjee et al. (2016) \\
\hline & Respiratory disease & GBP 1850 (2014) & 2603 & Burki (2017) \\
\hline & Cardiovascular disease & GBP 7600 (2015) & 10,492 & Bhatnagar et al. (2016) \\
\hline \multirow[t]{4}{*}{ Paris } & COPD & Euro 7924 (2015) & 9174 & Bourbeau et al. (2019) \\
\hline & Asthma & Euro 538 (2010) & 663 & Doz et al. (2013) \\
\hline & Respiratory disease & GBP 1850 (2014) & 2603 & Burki (2017) \\
\hline & Cardiovascular disease & Euro 4719 (2013) & 5541 & Tuppin et al. (2016) \\
\hline \multirow[t]{4}{*}{ Wuhan } & COPD & USD 4527 (2019) & 4527 & (Koul et al. 2019, Li et al. 2018) \\
\hline & Asthma & USD 1590 (2015) & 1721 & (Shan 2017) \\
\hline & Respiratory disease & USD 1089 (2016) & 1133 & (Li et al. 2018) \\
\hline & Cardiovascular disease & USD 2236 (2012) & 2581 & (Wang et al. 2015) \\
\hline
\end{tabular}

the reduction in functionality of an individual also leads to massive losses to the economy. This is often evaluated as DALY and is valued as well. For valuation, per capita income is used as a surrogate measure for the individuals getting effected along with DALYs associated with their diseases. The data related to DALY and per capita income based on city GDP averages is given in Table 4 and Table 5, respectively. The DALY-related valuation is carried out using Eq. (5). The morbidity valuation is shown in Table 9 while Fig. 3 represents a comparative loss of all cities due to AP morbidity in the years 2019 and 2020.

It can be seen from Fig. 3 that the highest benefit in terms of absolute numbers and in terms of percentage reduction of about $38 \%$ is seen by Delhi, which also happens to be one of the most polluted cities in the world. The lockdown scenario must have brought down the pollution levels drastically bringing a huge benefit to the city. In terms of change, Paris also sees a considerable reduction with morbidity damages reduced by almost $35 \%$. The city of Wuhan and London see a similar kind of drop in terms of percentage reduction of about 19 to $20 \%$. While the morbidity damages are in millions of dollars, it is evident that they have reduced considerably as compared to the previous year, indicating that the lockdown has improved air quality thereby saving of millions of dollars and more importantly an improved health and associated intangibles.

Mortality valuation is done using VSL, which is usually evaluated for low- to moderate-income groups in order to avoid overshooting the valuations. The value of statistical life for individuals staying in different countries is given in Table 3 and is used for the mortality

Table 7 Economic damage cost due to lockdown in each country of these cities

\begin{tabular}{|c|c|c|c|c|c|c|}
\hline City & $\begin{array}{l}\text { City GDP (1) B\$ (un- } \\
\text { less otherwise men- } \\
\text { tioned) }\end{array}$ & $\begin{array}{l}\text { Country GDP (2) B\$ } \\
\text { (unless otherwise men- } \\
\text { tioned) }\end{array}$ & $\begin{array}{l}\text { Ratio } \\
(3=1 / 2)\end{array}$ & $\begin{array}{l}\text { Economic } \\
\text { loss-country (4) } \\
(\mathrm{B} \$)\end{array}$ & $\begin{array}{l}\text { City economy } \\
\text { loss }(\mathrm{B} \$) \\
(5=4 \times 3)\end{array}$ & Author (year) \\
\hline Delhi & INR 8.56 billion & INR 231 billion & 00.04 & 00.14 & 05.36 & The Economic Times 2020 (2020) \\
\hline London & INR 8.56 billion & INR 231 billion & 00.25 & 74.40 & 18.60 & $\begin{array}{l}\text { Office of National Statistics (2019); Matt } \\
\text { and Martin (2020) }\end{array}$ \\
\hline Paris & 651.0 & 2470 & 00.26 & 60.00 & 15.81 & $\begin{array}{l}\text { Institut national de la statistique et des } \\
\text { etudes economiqu INSEE (2016); } \\
\text { France } 24 \text { (2020) }\end{array}$ \\
\hline Wuhan & 00.02 & 13.61 & 0.002 & 320.0 & 00.51 & $\begin{array}{l}\text { Trade commissioner service (2015); Lily } \\
\quad(2020)\end{array}$ \\
\hline
\end{tabular}


Table 8 Quantification of Impacts in terms of number of people affected due to pollutants

\begin{tabular}{|c|c|c|c|c|c|c|c|c|c|}
\hline \multirow[t]{3}{*}{ Pollutant } & \multirow[t]{3}{*}{ Health condition } & \multicolumn{8}{|l|}{ City } \\
\hline & & \multicolumn{2}{|l|}{ Delhi } & \multicolumn{2}{|c|}{ London } & \multicolumn{2}{|l|}{ Paris } & \multicolumn{2}{|l|}{ Wuhan } \\
\hline & & 2019 & 2020 & 2019 & 2020 & 2019 & 2020 & 2019 & 2020 \\
\hline \multirow[t]{5}{*}{$\mathrm{PM}_{2.5}$} & Total mortality & 14,089 & 9063 & 3195 & 2387 & 3707 & 2396 & 6829 & 5536 \\
\hline & Respiratory disease & 19,605 & 12,789 & 4256 & 3451 & 5335 & 3462 & 9467 & 7843 \\
\hline & Cardiovascular disease & 12,511 & 8013 & 2611 & 2095 & 3258 & 2104 & 6071 & 4965 \\
\hline & Chronic bronchitis & 30,620 & 20,218 & 6832 & 5579 & 8587 & 5593 & 14,728 & 12,312 \\
\hline & Asthma & 32,232 & 20,981 & 7489 & 5643 & 8730 & 5661 & 15,569 & 12,282 \\
\hline \multirow[t]{6}{*}{$\mathrm{PM}_{10}$} & Total mortality & 6121 & 1172 & 28 & 9 & 40 & 17 & 934 & 249 \\
\hline & Cardiovascular mortality & 4035 & 780 & 19 & 6 & 26 & 12 & 621 & 166 \\
\hline & Respiratory mortality & 718 & 141 & 3 & 1 & 5 & 2 & 111 & 30 \\
\hline & COPD morbidity & 692 & 133 & 3 & 1 & 5 & 2 & 106 & 28 \\
\hline & Respiratory disease & 6780 & 1281 & 31 & 10 & 44 & 19 & 1032 & 275 \\
\hline & Cardiovascular disease & 1289 & 243 & 6 & 2 & 8 & 4 & 194 & 51 \\
\hline \multirow[t]{6}{*}{$\mathrm{NO}_{2}$} & Total mortality & 0 & 0 & 168 & 0 & 206 & 0 & 106 & 0 \\
\hline & Cardiovascular mortality & 0 & 0 & 131 & 0 & 158 & 0 & 78 & 0 \\
\hline & Respiratory mortality & 0 & 0 & 23 & 0 & 28 & 0 & 14 & 0 \\
\hline & COPD morbidity & 0 & 0 & 12 & 0 & 14 & 0 & 7 & 0 \\
\hline & Respiratory disease & 0 & 0 & 98 & 0 & 118 & 0 & 58 & 0 \\
\hline & Cardiovascular disease & 0 & 0 & 54 & 0 & 65 & 0 & 32 & 0 \\
\hline
\end{tabular}

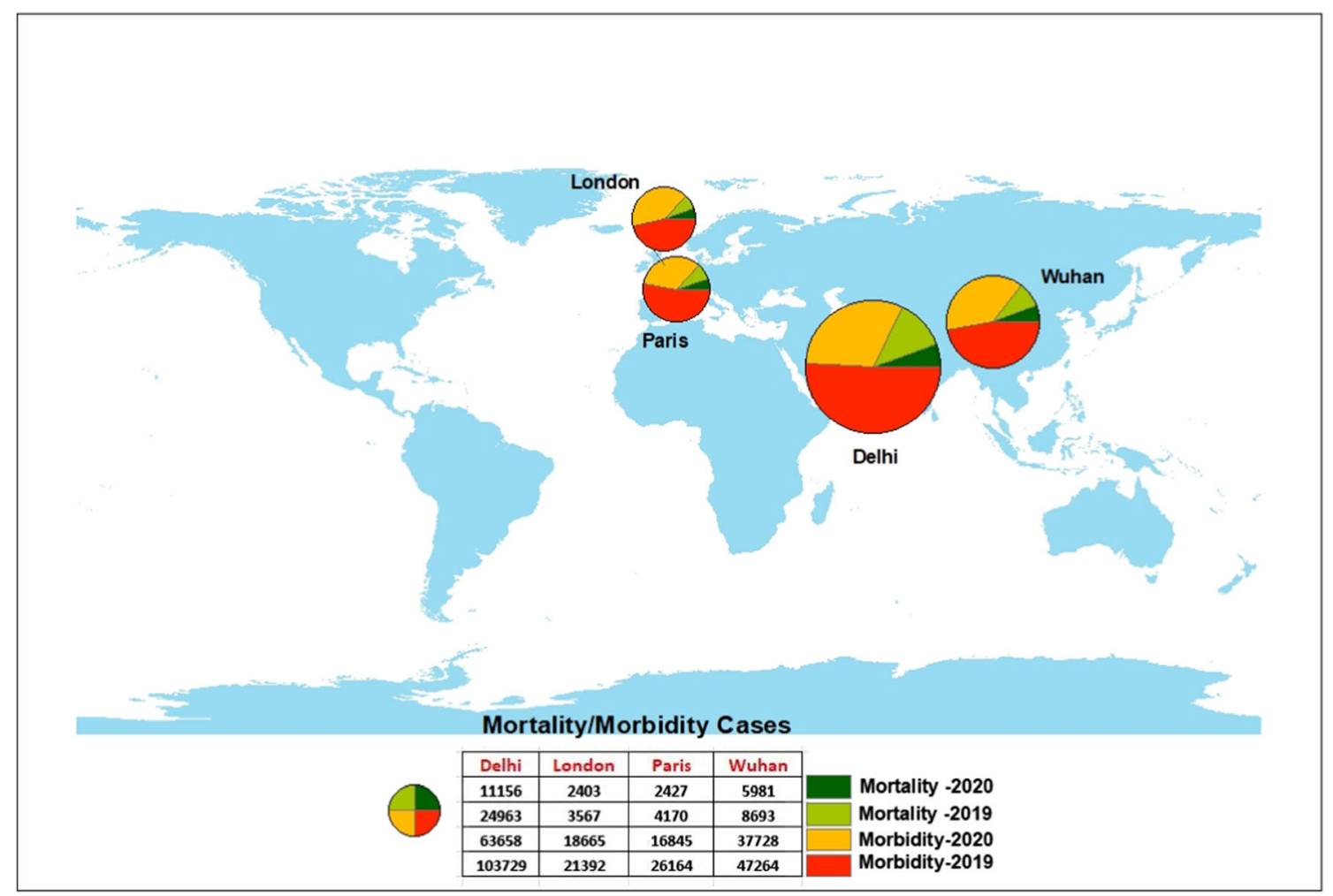

Fig. 2 Mortality and morbidity for the study period in 2020 as against 2019 
cases as evaluated by the relative risk and baseline incidences reported by WHO. Table 10 gives the mortality valuation under each category of disease for the respective pollutants. The equation used for valuation for mortality damages is given in the "Methodology" section as Eq. (4). Figure 4 gives a year-wise comparison of the benefits produced by lockdown in 2020 in terms of mortality reduction.

It is to be noted that mortality damages are reported as total mortality, and within that, there is respiratory and cardiovascular mortality. The total mortalities of particulate matter and nitrogen dioxide have been added to get the total value of damage related to mortality, which then further includes mortalities related to other factors of AP. A similar result is obtained as in case of morbidity. Delhi has the greatest benefit with almost $49 \%$ reduction in damages related to mortality due to lockdown followed by Paris with 39\% reduction, London with 29\%, and Wuhan having 26\% reduction. Further, in terms of absolute numbers, the reduction of damages is highest in Delhi, followed by London, Wuhan, and Paris, respectively.

Overall, mortality and morbidity represent the total loss due to AP in the select cities. The damages have been added and compared to the economic damages caused during the considered lockdown of these cities. The economic damages have been reported at the country level; the ratio of the GDPs of the corresponding cities is taken to normalize the damages for cities. The raw data with respect to economic damages and GDP ratios are given in Table 7 . The overall damages and economic damages are shown in Table 11.

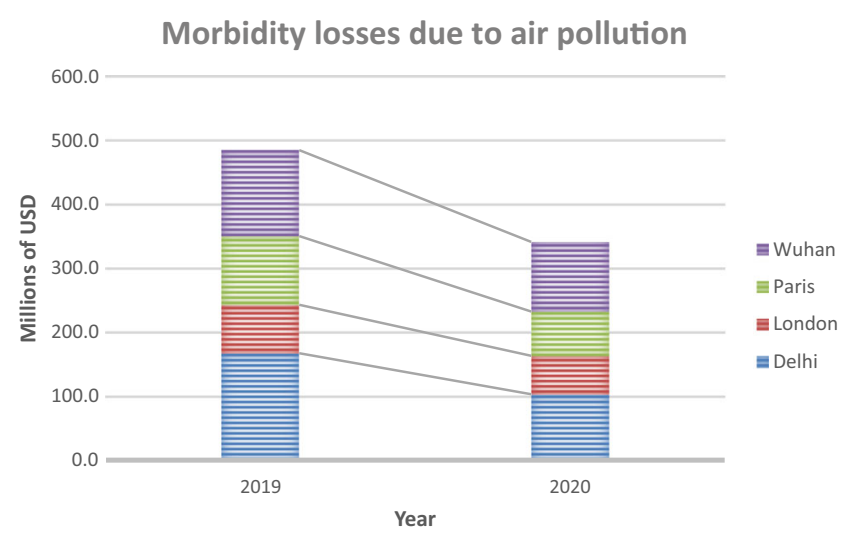

Fig. 3 Comparative morbidity losses for each city

Valuation of AP damages for 2019 and 2020 gives an understanding of the magnitude of damages which occurs due to AP. Due to lockdown, there is a drastic reduction in AP as indicated by 2020 scenario in Table 8 and Table 11, leading to the prevention of AP-related damages. It can be seen from Table 11 that the highest prevention happens in terms of absolute magnitude and percentage in Delhi. London has the second-highest amount of prevention in terms of absolute numbers but falls behind Paris in terms of percentage benefit. Wuhan has the lowest prevention in terms of magnitude and percentage.

When compared with the economic damages, as indicated in Fig. 5 above, actually Wuhan has the highest normalized benefit due to AP reduction, followed by Delhi, London, and Paris, respectively. This is evidently shown in terms of damage prevented per unit economic damage, which is highest for Wuhan 1.85 , followed by Delhi 1.19, London 0.11, and Paris 0.03.
Table 9 Morbidity valuation for diseases caused by air pollutants

\begin{tabular}{|c|c|c|c|c|c|c|c|c|}
\hline \multirow[t]{3}{*}{ Health condition } & \multicolumn{8}{|c|}{ Total morbidity(COI+DALY) valuation in M\$ } \\
\hline & \multicolumn{2}{|l|}{ Delhi } & \multicolumn{2}{|c|}{ London } & \multicolumn{2}{|l|}{ Paris } & \multicolumn{2}{|l|}{ Wuhan } \\
\hline & 2019 & 2020 & 2019 & 2020 & 2019 & 2020 & 2019 & 2020 \\
\hline Respiratory disease & 14.78 & 9.64 & 12.95 & 10.50 & 17.03 & 11.05 & 11.56 & 9.58 \\
\hline Cardiovascular disease & 60.72 & 38.89 & 33.23 & 26.66 & 25.67 & 16.58 & 24.05 & 19.67 \\
\hline Chronic bronchitis & 54.88 & 36.24 & 23.69 & 19.34 & 52.64 & 34.29 & 67.97 & 56.82 \\
\hline Asthma attack & 24.30 & 15.82 & 05.09 & 03.83 & 10.93 & 07.09 & 28.16 & 22.22 \\
\hline COPD morbidity & 01.24 & 00.24 & 00.01 & 00.00 & 00.05 & 00.02 & 00.49 & 00.13 \\
\hline Respiratory disease & 05.11 & 00.97 & 00.09 & 00.03 & 00.14 & 00.06 & 01.26 & 00.34 \\
\hline Cardiovascular disease & 06.26 & 01.18 & 00.08 & 00.03 & 00.06 & 00.03 & 00.77 & 00.20 \\
\hline COPD morbidity & 00.00 & 00.00 & 00.04 & 00.00 & 00.14 & 00.00 & 00.03 & 00.00 \\
\hline Respiratory disease & 00.00 & 00.00 & 00.30 & 00.00 & 00.38 & 00.00 & 00.07 & 00.00 \\
\hline Cardiovascular disease & 00.00 & 00.00 & 00.42 & 00.00 & 00.51 & 00.00 & 00.13 & 00.00 \\
\hline Total & 167.29 & 102.97 & 75.89 & 60.40 & 107.56 & 69.12 & 134.49 & 108.95 \\
\hline
\end{tabular}


Table 10 Mortality damages with respect to pollutants and respective diseases

\begin{tabular}{|c|c|c|c|c|c|c|c|c|c|}
\hline \multirow[t]{3}{*}{ Pollutant } & \multirow[t]{3}{*}{ Health condition } & \multicolumn{8}{|c|}{ Total mortality valuation in $\mathrm{B} \$$} \\
\hline & & \multicolumn{2}{|l|}{ Delhi } & \multicolumn{2}{|c|}{ London } & \multicolumn{2}{|l|}{ Paris } & \multicolumn{2}{|c|}{ Wuhan } \\
\hline & & 2019 & 2020 & 2019 & 2020 & 2019 & 2020 & 2019 & 2020 \\
\hline $\mathrm{PM}_{2.5}$ & Total $\mathrm{PM}_{2.5}$ mortality (1) & 08.94 & 05.75 & 06.66 & 04.97 & 1.04 & 0.67 & 03.11 & 02.52 \\
\hline \multirow[t]{3}{*}{$\mathrm{PM}_{10}$} & Total $\mathrm{PM}_{10}$ mortality (2) & 03.89 & 00.74 & 00.06 & 00.02 & 0.01 & 0.00 & 00.42 & 00.11 \\
\hline & Cardiovascular mortality & 02.56 & 00.50 & 00.04 & 00.01 & 0.01 & 0.00 & 00.28 & 00.08 \\
\hline & Respiratory mortality & 00.46 & 00.09 & 00.01 & 00.00 & 0.00 & 0.00 & 00.05 & 00.01 \\
\hline \multirow[t]{3}{*}{$\mathrm{NO}_{2}$} & Total $\mathrm{NO}_{2}$ mortality (3) & 00.00 & 00.00 & 00.35 & 00.00 & 0.06 & 0.00 & 00.05 & 00.00 \\
\hline & Cardiovascular mortality & 00.00 & 00.00 & 00.27 & 00.00 & 0.04 & 0.00 & 00.04 & 00.00 \\
\hline & Respiratory mortality & 00.00 & 00.00 & 00.05 & 00.00 & 0.01 & 0.00 & 00.01 & 00.00 \\
\hline \multicolumn{2}{|c|}{ Total mortality $(1+2+3)$} & 12.83 & 06.50 & 07.07 & 04.99 & 1.10 & 0.67 & 03.58 & 02.63 \\
\hline
\end{tabular}

\section{Conclusion}

This study highlights that although the world is fighting with COVID-19 and suffering from huge economic losses, due to reduced cohesive situation for work, the environment is benefitted. This further is demonstrated in monetary terms for reduced health damages related to air pollution. The exposure and impact assessment is carried out for Delhi, London, Paris, and Wuhan, using relative risk and baseline indices of various air pollutants including $\mathrm{PM}_{2.5}, \mathrm{PM}_{10}$, and $\mathrm{NO}_{2}$. The study further incorporates monetization of the impacts for 2019 and 2020, to gauge the magnitude of impact reduction of air pollution under COVID-19 lockdown scenario. The monetary assessment of damages is done using econometric approaches like VSL, CoI, and PCI for DALY. The key conclusions are summarized as follows:

1. $\mathrm{PM}_{2.5}$ is one of the major contributors to the burden of disease related to AP. Delhi, being one of the

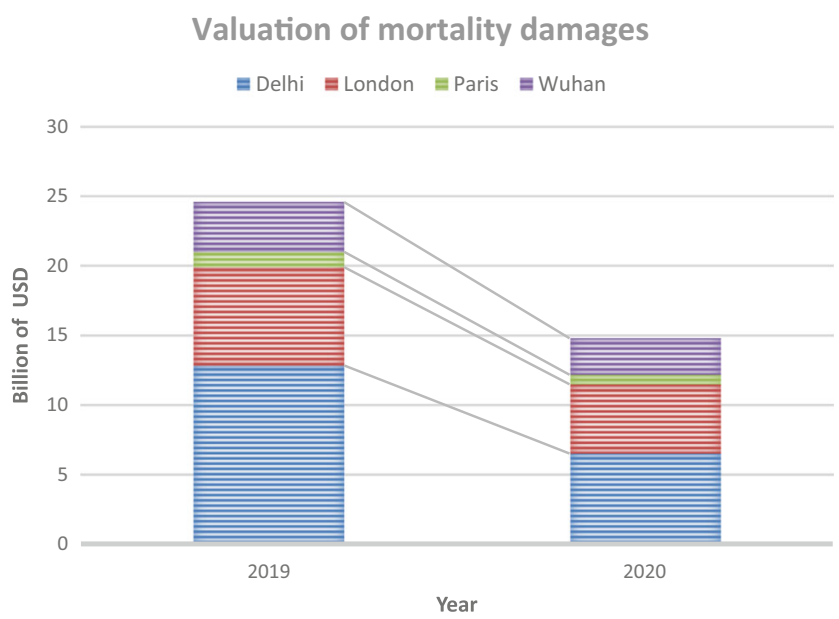

Fig. 4 Mortality damages for air pollutants for 2019 and 2020 most polluted cities globally, is the worst affected. $\mathrm{PM}_{10}$ and $\mathrm{NO}_{2}$ impacts are also considerable, while $\mathrm{SO}_{2}$ is found within WHO guidelines limits for both 2019 and 2020. Monetarily, the impact is curtailed by average $36 \%$ in mortality and about $28 \%$ in morbidity in the year 2020 due to substantial reduction in AP amid reduced anthropogenic activities owing to COVID-19 lockdown. In terms of an absolute number of people affected, an average $31 \%$ reduction is for combined mortality and morbidity for all cities. Impacts of $\mathrm{NO}_{2}$ are zeroed for the year 2020. For $\mathrm{PM}_{2.5}$ mortality cases, Delhi sees the highest fall in the number of cases for 2020 from 2019, followed by Paris, Wuhan, and London, in that order.

2. Morbidity damages estimated using $\mathrm{CoI}$ and PCI for DALY indicates that exposure impact is highest for Delhi followed by Wuhan, Paris, and London for 2019, reporting damages worth 167.3 M\$ (million USD, 2019), 134.5 M\$, 107.6 M\$, and 75.9 M\$, respectively. A major reduction in morbidity damages is seen in Delhi in 2020 because of lockdown, revealing reduction of damages worth $64.3 \mathrm{M} \$$, with Paris falling in second place with $38.4 \mathrm{M} \$$ worth of reduction, trailed by Wuhan and London at $25.5 \mathrm{M} \$$ and $15.5 \mathrm{M} \$$ reductions respectively. This indicates that lockdown has affected cities differently, indicating there are potentially other factors like geographic location, background concentration, seasonality, and meteorological parameters playing a major role in alleviating the damages.

3. While morbidity damages are in millions of dollars, the mortality damages extend that to multiple order of magnitudes. The 2019 estimates suggest that the absolute mortality damages are highest for Delhi at 12.8 billion USD (B \$, 2019) and achieved a maximum reduction of $49 \%$ in 2020 lockdown. The 
Table 11 Consolidated results in comparison to economic damage for cities

\begin{tabular}{lllllllll}
\hline City & $\begin{array}{l}\text { Days } \\
\text { (a) }\end{array}$ & $\begin{array}{l}\text { 2019 AP } \\
\text { damage } \\
\text { (B\$) }(1)\end{array}$ & $\begin{array}{l}2020 \text { AP } \\
\text { damage } \\
\text { (B\$) }(2)\end{array}$ & $\begin{array}{l}\text { Prevention due to } \\
\text { lockdown }(\mathrm{B} \$) \\
(3=1-2)\end{array}$ & $\begin{array}{l}\text { Percentage } \\
\text { reduction in 2020 } \\
(\%)(100 \times 3 / 1)\end{array}$ & $\begin{array}{l}\mathrm{B} \$ \\
\text { prevented/ } \\
\text { day (3/a) }\end{array}$ & $\begin{array}{l}\text { Economic damage } \\
\text { due to lockdown } \\
(\mathrm{B} \$)(4)\end{array}$ & $\begin{array}{l}\text { AP damage prevented per } \\
\text { unit economic damage } \\
(5=3 /(-4))\end{array}$ \\
\hline Delhi & 31 & 13.00 & 06.60 & 06.40 & $49 \%$ & 00.21 & -05.36 & 01.19 \\
London & 31 & 07.14 & 05.05 & 02.09 & $29 \%$ & 00.07 & -18.60 & 00.11 \\
Paris & 31 & 01.21 & 00.74 & 00.47 & $39 \%$ & 00.02 & -15.81 & 00.03 \\
Wuhan & 31 & 03.71 & 02.74 & 00.97 & $26 \%$ & 00.03 & -00.53 & 01.85 \\
\hline
\end{tabular}

damages in London are recorded as second highest at $7 \mathrm{~B} \$$; however, the recovery is second lowest at $29 \%$, second to Wuhan having recovery of $26 \%$. Wuhan suffered damage of 3.5 B \$ in 2019 and 2.6 $\mathrm{B} \$$ in 2020 . Paris had the lowest damages of $1.1 \mathrm{~B} \$$ in 2019 and made a reduction of about $39 \%$ in 2020 . It can be seen the trend in mortality damages between the cities is not similar to morbidity, indicating that there could be other compounding factors like age, life expectancy, and standard of living in these cities.

4. The total of morbidity and mortality damages reduction in 2020 is compared with the economic damages being reported for the cities. It is reported that London (18.6B\$) suffered maximum economic damage during its respective lockdown days, while Wuhan suffered the lowest $(0.56 \mathrm{~B} \$)$. Paris $(15.81 \mathrm{~B} \$)$ and Delhi $(5.36 \mathrm{~B} \$)$ suffered the second-highest and lowest damages, respectively. Delhi, London, Wuhan, and Paris prevented AP damages worth 6.4B \$, 2.09B $\$, 0.97 \mathrm{~B} \$$, and $0.47 \mathrm{~B} \$$, respectively, in 2020 . This indicates that Wuhan and Delhi could extract better worth from prevention of damages from lockdown as compared to their lockdown losses. This might be due to the fact that both these cities are highly polluted as compared to Paris and London and are economically developing as well. Wuhan is actually higher as the economic damages incurred by that city are the lowest. The lowest recovery is made by Paris, while London stands at second-lowest.

It is apparent that while quantifying AP damages in terms of exposure and affected population is fruitful, there are more insights which can be explored to understand the true magnitude of the damage caused by it. The monetary evaluation gives a common denomination for comparison and for making a rational decision for policy formulation. The above research of four major global cities demonstrates that while the world is suffering from enormous economic damage, the lockdown has created some positive for the air environment and hence the human health as well. While the above analysis might hold true for the majority of the cities suffering from a probable of $\mathrm{AP}$, a detailed analysis should be carried out for the respective city before making decisions. Accounting of the cost and benefits due to halting of anthropogenic activities gives us a clear indication of the change of damage being incurred on the ecosystem and on human health. It further suggests that stronger policies are needed to safeguard the ecosystem balance.

Acknowledgments Authors acknowledge Council of Scientific and Industrial Research (CSIR), India, and its constituent laboratory National Environmental Engineering Research Institute (NEERI) for providing the support for the research. The manuscript is checked for plagiarism using licensed iThenticate software wide KRC No.: CSIR-NEERI/ KRC/2020/MAY/CSUM-DRC-DIR/1.
Fig. 5 AP damage prevented due to lockdown in comparison to economic damage

\section{Air pollution damages vs economic damages}

E Prevention due to Lockdown

E Economic Damage due to Lockdown

- AP Damage Prevented per unit economic damage

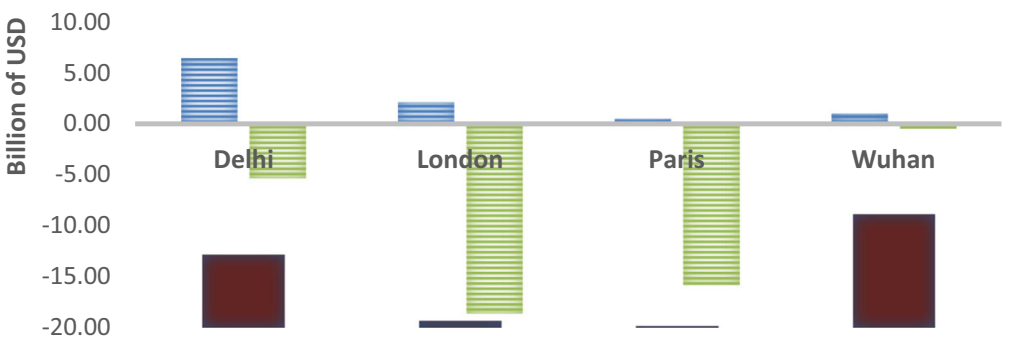




\section{References}

Bhatnagar P, Wickramasinghe K, Wilkins E, Townsend N (2016) Trends in the epidemiology of cardiovascular disease in the UK. Heart 102(24):1945-1952

Bherwani H, Gupta A, Nair M, Sonwani H, Kumar R (2019) Framework for environmental damages cost assessment with examples. Special Report on Monetising Damages. Nagpur: CSIR-National Environmental Engineering Research Institute (NEERI). https:// www.neeri.res.in/file homes/41441989 EDCA Final Soft.pdf. Accessed 16 May 2020

Bherwani H, Gupta A, Anjum S, Anshul A, Kumar R (2020) Exploring dependence of COVID-19 on environmental factors and spread prediction in India. Research Square. https://doi.org/10.21203/rs.3.rs$25644 / \mathrm{v} 1$

Bourbeau J, Granados D, Roze S, Durand-Zaleski I, Casan P, Köhler D, Tognella S, Viejo JL, Dal Negro RW, Kessler R (2019) Costeffectiveness of the COPD Patient Management European Trial home-based disease management program. Int J Chron Obstruct Pulmon Dis 14(14):645-657

Burki TK (2017) The economic cost of respiratory disease in the UK. Lancet Resp Med 5(5):381

CEIC (2018) China CN: GDP: per capita: Hubei: Wuhan. Retrieved march 2, 2020 from (https://www.ceicdata.com/en/china/gross-domestic-product-per-capita-prefecture-level-city/cn-gdp-per-capitahubei-wuhan)

Cohen AJ, Brauer M, Burnett R, Anderson HR, Frostad J, Estep K, Balakrishnan K, Brunekreef B, Dandona L, Dandona R, Feigin V, Freedman G, Hubbell B, Jobling A, Kan H, Knibbs L, Liu Y, Martin R, Morawska L, Pope CA III, Shin H, Straif K, Shaddick G, Thomas M, van Dingenen R, van Donkelaar A, Vos T, Murray CJL, Forouzanfar MH (2017) Estimates and 25-year trends of the global burden of disease attributable to ambient air pollution: an analysis of data from the Global Burden of Diseases Study 2015. Lancet 389(10082):1907-1918

Doz M, Chouaid C, Com-Ruelle L, Calvo E, Brosa M, Robert J, Decuypère L, Pribil C, Huerta A, Detournay B (2013) The association between asthma control, health care costs, and quality of life in France and Spain. BMC Pulmon Med 13(1):15

Dutheil F, Baker JS, Navel V (2020) COVID-19 as a factor influencing air pollution?. Environ Pollut 263(Pt A):114466

Economic Times (2020) India will be under lockdown for 21 days. Retrieved March 25, 2020 from (https://economictimes.indiatimes. $\mathrm{com} /$ news/politics-and-nation/india-will-be-under-completelockdown-starting-midnight-narendra-modi/articleshow/74796908. cms?from=mdr )

Economic Survey of Delhi (2019) Planning Department, Government of NCT of Delhi. Retrieved January 25, 2020 from (http:// delhiplanning.nic.in/sites/default/files/Final\%20Economy\% 20survey\%20English.pdf)

European Commission (2019) Internal Market, Industry, Entrepreneurship and SMEs. Retrieved March 20, 2020 from (https://ec.europa.eu/growth/tools-databases/regional-innovationmonitor/base-profile/ile-de-france-0)

France 24 (2020) Two months of Covid-19 lockdown will cost France $€ 120$ billion, report says. https://www.france24.com/en/20200420france-s-lockdown-to-cost-\%E2\%82\% AC120-billion-in-lostrevenue; Accessed April 20, 2020)

Gautam S, Hens L (2020) SARS-CoV-2 pandemic in India: what might we expect? Environ Develop Sustain 22:3867-3869

Gautam S, Trivedi UK (2020) Global implication of bioaerosol in pandemic. Environ Develop Sustain 22:3861-3865

Gautam S (2020a) The influence of COVID - 19 on air quality in India: a boon or inutile. Bulletin of Environmental Contamination and
Toxicology 104:724-726. https://doi.org/10.1007/s00128-02002877-y

Gautam S (2020b) COVID - 19: air pollution remains low as people stay at home. Air Qual Atmos Health. https://doi.org/10.1007/s11869020-00842-6

Gautam S, Kumar P, Patra AK (2016) Occupational exposure to particulate matter in three Indian opencast mines. Air Qual Atmos Health 9(2):143-158

Ghorani-Azam A, Riahi-Zanjani B, Balali-Mood M (2016) Effects of air pollution on human health and practical measures for prevention in Iran. J Res Med Sci 21:65. https://doi.org/10.4103/1735-1995. 189646

Ghoshal AG, Ravindran GD, Gangwal P, Rajadhyaksha G, Cho SH, Muttalif ARBA, Lin HC, Thanaviratananich S, Bagga S, Faruqi R, Sajjan S, Shetty P, Syed R, Hamrosi KK, Wang DY (2016) The burden of segregated respiratory diseases in India and the quality of care in these patients: results from the Asia-Pacific Burden of Respiratory Diseases study. Lung India: official organ of Indian Chest Society 33(6):611-619

Gulia S, Nagendra SS, Khare M, Khanna I (2015) Urban air quality management-a review. Atmos Pollut Resea 6(2):286-304

Gupta A, Mulukutla AN, Gautam S, TaneKhan W, Waghmare SS, Labhasetwar NK (2020) Development of a practical evaluation approach of a typical biomass cookstove. Environ Technol Inno 17: 100613

Humbal C, Joshi SK, Trivedi UK, et al (2019) Evaluating the colonization and distribution of fungal and bacterial bio-aerosol in Rajkot, western India using multi-proxy approach. Air Qual Atmos Health 12: 693-704. https://doi.org/10.1007/s11869-019-00689-6

International Monetory Fund (IMF) (2020) Exchange Rate Arrives by Month. (https://www.imf.org/external/np/fin/data/param rms mth. aspx; Accessed May 6, 2020)

Institut national de la statistique et des etudes economiques (INSEE) (2016) Statistique et etudes. https://www.insee.fr/fr/statistiques; Accessed 1 April 2016)

Jon H, Kim W (2020) Ashifa corona virus: France imposes lockdown as EU calls for 30-day travel ban March 16, 2020. https://www. theguardian.com/world/2020/mar/16/coronavirus-spain-takes-overprivate-healthcare-amid-more-european-lockdowns. Accessed on 17 May 2020

Jordan D (2020) India's air pollution plummets in COVID-19 Lockdown. https://www.ecowatch.com/india-air-pollution-coronavirus2645617908.html?rebelltitem=1\#rebelltitem1. Accessed on 18 May 2020

Kim KH, Kabir E, Kabir S (2015) A review on the human health impact of airborne particulate matter. Environ Inte 74:136-143

Koul PA, Nowshehr AA, Khan UH, Jan RA, Shah SU (2019) Cost of severe chronic obstructive pulmonary disease exacerbations in a high burden region in North India. Ann Glob Health 85(1):13

Landrigan PJ, Fuller R, Acosta NJR, Adeyi O, Arnold R, Basu N(N), Baldé AB, Bertollini R, Bose-O'Reilly S, Boufford JI, Breysse PN, Chiles T, Mahidol C, Coll-Seck AM, Cropper ML, Fobil J, Fuster V, Greenstone M, Haines A, Hanrahan D, Hunter D, Khare M, Krupnick A, Lanphear B, Lohani B, Martin K, Mathiasen KV, McTeer MA, Murray CJL, Ndahimananjara JD, Perera F, Potočnik J, Preker AS, Ramesh J, Rockström J, Salinas C, Samson LD, Sandilya K, Sly PD, Smith KR, Steiner A, Stewart RB, Suk WA, van Schayck OCP, Yadama GN, Yumkella K, Zhong M (2018) The lancet commission on pollution and health. Lancet 391(10119):462-512

Li M, Wang F, Chen R, Liang Z, Zhou Y, Yang Y, Chen S, Ung COL, $\mathrm{Hu} \mathrm{H}$ (2018) Factors contributing to hospitalisation costs for patients with COPD in China: a retrospective analysis of medical record data. Int J Chron Obstruct Pulmon Dis 13:3349-3357

Lily K (2020) China economy shrinks as coronavirus hits world trade. https://www.theguardian.com/world/2020/apr/17/china-economy- 
shrinks-record-wuhan-covid-19-death-toll-rises-50-percent; Accessed April 17, 2020

Mage D, Ozolins G, Peterson P, Webster A, Orthofer R, Vandeweerd V, Gwynne M (1996) Urban air pollution in megacities of the world. Atmos Environ 30(5):681-686

Maji KJ, Dikshit AK, Deshpande A (2017) Assessment of city level human health impact and corresponding monetary cost burden due to air pollution in India taking Agra as a model city. Aerosol Air Qual Res 17(3):831-842

Maji KJ, Ye WF, Arora M, Nagendra SS (2018) PM2. 5-related health and economic loss assessment for 338 Chinese cities. Environ Int 121:392-403

Majumder A, Madheswaran S (2018) Value of statistical life in India: a hedonic wage approach. Institute for Social and Economic Change

Matt O, Martin D (2020) Revealed: lockdown is costing Britain £2.4billion a DAY with young workers and women the worst hit. https:// www.dailymail.co.uk/news/article-8190111/Coronaviruslockdown-costing-Britain-2-4billion-DAY-national-output-slashed31-percent.html (Accessed April 6, 2020)

Monzón A, Guerrero MJ (2004) Valuation of social and health effects of transport-related air pollution in Madrid (Spain). Sci Tot Environ $334: 427-434$

Mukherjee M, Stoddart A, Gupta RP, Nwaru BI, Farr A, Heaven M, Fitzsimmons D, Bandyopadhyay A, Aftab C, Simpson CR, Lyons RA, Fischbacher C, Dibben C, Shields MD, Phillips CJ, Strachan DP, Davies GA, McKinstry B, Sheikh A (2016) The epidemiology, healthcare and societal burden and costs of asthma in the UK and its member nations: analyses of standalone and linked national databases. BMC Med 14:113

Nair M, Bherwani H, Kumar S, Gulia S, Goyal S, Kumar R (2020) Assessment of contribution of agricultural residue burning on air quality of Delhi using remote sensing and modelling tools. Atmos Environ 230:117504

Nakada LYK, Urban RC (2020) COVID-19 pandemic: impacts on the air quality during the partial lockdown in São Paulo state, Brazil Sci Tot Environ 139087

Office for National Statistics (2019) GDP of London : January - March 2019. https://www.ons.gov.uk/economy/grossdomesticproductgdp/bulletins/ gdplondon/januarytomarch2019; Accessed October 30, 2019

PRS Legislative Research (2019) Delhi Budget Analysis, 2019-2020. https://www.prsindia.org/sites/default/files/budget files/Delhi\% 20Budget\%20Analysis\%20-\%202019-20.pdf; Accessed March 11, 2019

Qu Z, Wang X, Li F, Li Y, Chen X, Chen M (2020) PM2. 5-related health economic benefits evaluation based on air improvement action plan in Wuhan City, middle China. Int J environ Resea pub health 17(2): 620

Shan J (2017) Study finds little control of asthma. Retrieved may 3, 2017 from (https://www.chinadaily.com.cn/china/2017-05/03/content 29178799.htm)

Sharma S, Zhang M, Gao J, Zhang H, Kota SH (2020) Effect of restricted emissions during COVID-19 on air quality in India. Sci Tot Environ $728: 138878$

Starkie HJ, Briggs AH, Chambers MG (2008) Pharmacoeconomics in COPD: lessons for the future. Int J Chron Obstruct Pulmon Dis 3(1):71-88
The Economic Times (2020) World's biggest lockdown may have cost Rs 7-8 lakh crore to Indian economy. Retrieved April 13, 2020 from (https://economictimes.indiatimes.com/news/economy/finance/ worlds-biggest-lockdown-may-have-cost-rs-7-8-lakh-crore-toindian economy/articleshow/75123004.cms?from=mdr)

The Hindu (2020) Britain imposes lockdown to combat spread of corona virus. Retrieved March 24, 2020 from (https:/www.thehindu.com/ news/international/britain-imposes-lockdown-to-combat-spread-ofcoronavirus/article31148706.ece)

The World Bank (2019) Inflation consumer prices (annual \%). Retrieved March 23, 2020 from (https://data.worldbank.org/indicator/FP.CPI. TOTL.ZG)

Thomas P (2018) Calculating the value of human life: safety decisions that can be trusted. University of Bristol, Bristol. https://www. bristol.ac.uk/media-library/sites/policybristol/PolicyBristol-ReportApril-2018-value-human-life.pdf. Accessed 18 May 2020

Tobías A, Carnerero C, Reche C, Massagué J, Via M, Minguillón MC, Alastuey A, Querol X (2020) Changes in air quality during the lockdown in Barcelona (Spain) one month into the SARS-CoV-2 epidemic. Sci Tot Environ 726:138540

Trade Commissioner Service (2015) Focus on Wuhan, China. Retrieved January 2, 2020 from (https://www.tradecommissioner.gc.ca/chinachine/market-facts-faits-sur-le-marche/96289.aspx?lang=eng)

TUC (2016) London's economic income per capita is double that of rest of the UK https://www.tuc.org.uk/news/london\%E2\%80\%99seconomic-income-capita-double-rest-uk. Accessed 16 May 2020

Tuppin P, Rivière S, Rigault A, Tala S, Drouin J, Pestel L, Denis P, Gastaldi-Ménager C, Gissot C, Juillière Y, Fagot-Campagna A (2016) Prevalence and economic burden of cardiovascular diseases in France in 2013 according to the national health insurance scheme database. Arch Cardiovasc Dis 109(6-7):399-411

Wang S, Petzold M, Cao J, Zhang Y, Wang W (2015) Direct medical costs of hospitalizations for cardiovascular diseases in Shanghai, China. Medicine 94(20):e837. https://doi.org/10.1097/MD. 0000000000000837

Wang C, Horby PW, Hayden FG, Gao GF (2020a) A novel coronavirus outbreak of global healthconcern. Lancet 395(10223):470-473

Wang P, Chen K, Zhu S, Wang P, Zhang H (2020b) Severe air pollution events not avoided by reduced anthropogenic activities during COVID-19 outbreak. Resour Conserv Recycl 158:104814

World Health Organization (2006) Air quality guidelines: global update 2005: particulate matter, ozone, nitrogen dioxide, and sulfur dioxide. Retrieved March 14, 2020 from (https://apps.who.int/iris/handle/ 10665/69477)

World Health Organization (2018) Metrics: disability-adjusted life year (daly): Quantifying the burden of disease from mortality and morbidity. Retrieved February 12, 2020

World Health Organization (2020) Coronavirus disease (COVID-2019) situation reports. Geneva: World Health Organization. Retrieved March 23, 2020 from (https://www.who.int/emergencies/diseases/ novel-coron avirus-2019/situation-reports/.opens in new tab)

Publisher's note Springer Nature remains neutral with regard to jurisdictional claims in published maps and institutional affiliations. 